\title{
Soil weathering rates in 21 catchments of the Canadian Shield
}

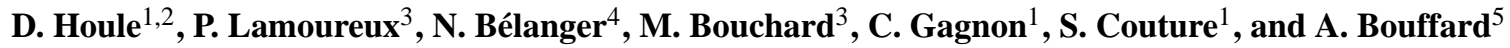 \\ ${ }^{1}$ Centre Saint-Laurent, Environnement Canada, 105 rue McGill, Montréal, Québec, H2Y 2E7, Canada \\ ${ }^{2}$ Direction de la recherche forestière, Forêt Québec, Ministère des Ressources naturelles et de la Faune du Québec, \\ 2700, rue Einstein, Sainte-Foy, Québec, G1P 3W8, Canada \\ ${ }^{3}$ Département de géographie, Université du Québec à Montréal, C.P. 8888, succursale Centre-ville, \\ Montréal, QC, H3C 3P8, Canada \\ ${ }^{4}$ UER Sciences et technologies, Téluq, Université du Québec à Montréal, 100 rue Sherbrooke Ouest, \\ Montréal, QC, H2X 3P2, Canada \\ ${ }^{5}$ Consortium Ouranos, 550 rue Sherbrooke ouest, 19 e étage, Montréal, Québec, H3A 1B9, Canada
}

Correspondence to: D. Houle (daniel.houle@mrnf.gouv.qc.ca)

Received: 29 March 2011 - Published in Hydrol. Earth Syst. Sci. Discuss.: 20 June 2011

Revised: 7 February 2012 - Accepted: 20 February 2012 - Published: 6 March 2012

\begin{abstract}
Soil mineral weathering represents an essential source of nutrient base cation $(\mathrm{Ca}, \mathrm{Mg}$ and $\mathrm{K})$ for forest growth in addition to provide a buffering power against precipitation acidity for soils and surface waters. Weathering rates of base cations were obtained for 21 catchments located within the temperate and the boreal forest of the Canadian Shield with the geochemical model PROFILE. Weathering rates ranged from 0.58 to $4.46 \mathrm{kmol}_{\mathrm{c}} \mathrm{ha}^{-1} \mathrm{yr}^{-1}$ and their spatial variation within the studied area was mostly in agreement with spatial variations in soil mineralogy. Weathering rates of $\mathrm{Ca}$ and $\mathrm{Mg}$ were significantly correlated $(r=0.80$ and $0.64)$ with their respective lake concentrations. Weathering rates of $\mathrm{K}$ and $\mathrm{Na}$ did not correlate with lake concentrations of $\mathrm{K}$ and $\mathrm{Na}$. The modeled weathering rates for each catchment were also compared with estimations of net catchment exportations. The result show that modeled weathering rates of Ca were not significantly different than the net catchment exportations while modeled weathering rates of $\mathrm{Mg}$ were higher by $51 \%$. Larger differences were observed for $\mathrm{K}$ and $\mathrm{Na}$ weathering rates that were significantly different than net catchment exportations being 6.9 and 2.2 times higher than net exportations, respectively. The results for $\mathrm{K}$ were expected given its high reactivity with biotic compartments and suggest that most of the K produced by weathering reactions was retained within soil catchments and/or above ground biomass. This explanation does not apply to $\mathrm{Na}$, however, which is a conservative element in forest ecosystems because of the insignificant needs of $\mathrm{Na}$ for soil microorganisms and
\end{abstract}

above ground vegetations. It raises concern about the liability of the PROFILE model to provide reliable values of $\mathrm{Na}$ weathering rates. Overall, we concluded that the PROFILE model is powerful enough to reproduce spatial geographical gradients in weathering rates for relatively large areas as well as adequately predict absolute weathering rates values for the sum of base cations, $\mathrm{Ca}$ and $\mathrm{Mg}$.

\section{Introduction}

Atmospheric deposition and weathering of soil minerals represent the two major (primary) sources of nutrient base cations $(\mathrm{Ca}, \mathrm{Mg}$ and $\mathrm{K}$, later referred as $\mathrm{BC}$ ) and phosphorus to forest ecosystems. For this reason, weathering rates (WRs, thereafter) are often estimated in a variety of studies on tree $\mathrm{BC}$ nutrition, $\mathrm{BC}$ cycling and mass balance of $\mathrm{BC}$ at the forest plot, stand and the watershed scales (e.g., April et al., 1986; Taylor and Velbel, 1991; Likens and Bormann, 1995; Anderson et al., 2002; Bélanger et al., 2004). Weathering rates are also crucial in the equation used for calculating acidic critical loads for forest soils and surface waters (Hodson and Langan, 1999a). Chemical weathering of silicate minerals also involves the consumption of $\mathrm{CO}_{2}$ which is released as $\mathrm{HCO}_{3}^{-}$in surface waters and could eventually reach the oceans where it could precipitate as carbonates (Garrels and Mackenzie, 1971; Gislason et al., 2009). Due to their critical importance, several quantification methods have been 
developed, but these require more refinement (e.g., Hodson et al., 1996, 1997).

Among those methods, the pedological mass balance approach (Brimhall and Dietrich, 1987; Kirkwood and Nesbitt, 1991) provides estimates of WRs by analysing the enrichment (or depletion) factor of certain elements as compared to non-mobile elements ( $\mathrm{Ti}$ or $\mathrm{Zr}$ ) in the soil profile, taking into account changes in soil horizon thickness and density due to pedogenesis since the parent material was emplaced. This method provides long-term (thousands of years) averages of WRs. It has been shown, however, that WRs may vary over such long periods of time (Hodson and Langan, $1999 b$ ), making the use of long-term averages questionable for detailed studies of BC budget in the present time.

The catchment mass balance approach is based on the assumption that steady state conditions exist in BC fluxes due to relatively stable tree uptake rates and weathering fluxes and that the size of the soil exchangeable BC pools does not change significantly over time. In these conditions, the net $\mathrm{BC}$ output from the catchment (exports at the stream outlet minus atmospheric inputs) is equal to the WRs.

Another common approach is the use of biogeochemical models that can calculate weathering rates based on mineralogy and sites characteristics data. Among them, the WITCH model has been used to model weathering rates on a seasonal basis at the catchment scale for the Strengbach watershed in France (Goddéris et al., 2006). One of the best known geochemical model is PROFILE which has been initially developed to estimate WRs for granitic soils with relatively low weathering potential in Sweden (e.g., Sverdrup and Warfvinge, 1993, 1995). Since then, it has been used for studies of weathering or BC cycling, at the plot or the catchment scale (Eggenberger and Kurz, 2000; Bélanger et al., 2004; Whitfield et al., 2006: Duchesne et Houle, 2006, 2008; Houle et al., 2010) and at a much larger regional scale (Akselsson et al., 2004). One advantage of these types of models is that they can be used to provide weathering rates on a regional basis for large scale studies of critical load mappings for instance. PROFILE is a steady-state model that calculates the soil solution chemical composition based on a complex mathematical and schematic description of a forest soil. The model follows kinetic rate laws (Sverdrup, 1990) that generate yearly WRs for individual BC, Na, P, $\mathrm{Al}$ and $\mathrm{Si}$. Input variables for which PROFILE is sensitive are mineralogy, specific surface area, soil water content, and soil temperature. These input variables have significant impacts on the model output because they determine the amount and type of weatherable surfaces available as well as the kinetics of the weathering reactions. Previous comparisons of the model's performance with independent estimations of weathering showed that the error associated with simulated WRs was below $40 \%$ for three Nordic sites in Sweden (Jönsson et al., 1995). Ouimet and Duchesne (2005) also compared different approaches for estimating WRs and concluded that PROFILE values were relatively similar with the values obtained with other approaches for three watersheds in the province of Quebec. Kolka et al. (1996) compared four different approaches for five different forested sites, and again, estimates from PROFILE fell within the range obtained with other approaches. Hodson et al. (1997) suggested that unrealistic constraints imposed with the soil surface area input parameter may be responsible for the model's success in reproducing field-measured WRs in most systems. The above studies have in common that only a few sites were compared together at the same time as a means to validate the model. As a result, the robustness of the statistical comparisons was suffering from the low number of replication and correlation analysis between different methods was not possible. In addition, comparison of weathering rates often focused on total $\mathrm{BC}$ while weathering rates of individual cation $(\mathrm{Ca}, \mathrm{Mg}, \mathrm{K}$ and $\mathrm{Na}$ ) received less attention. Although, the total $\mathrm{BC}$ weathering rates values provided by PROFILE were suggested to be adequate in some studies, it does not ensure that weathering rates of individual $\mathrm{BC}$ are. This point is important since each cation has different behaviors in forest ecosystems. For example, $\mathrm{Na}$, because of its conservative behavior, can be used as an index of weathering and/or as a reference element to which other nutritive base cation can be expressed in the form of a ratio (Bailey et al., 2002). Also, impoverishment of soil exchangeable reservoirs and limitation of forest growth is often associated with a specific cation such as $\mathrm{Ca}$ (Houle et al., 1997) or K (Duchesne and Houle, 2006, 2008). In consequence, to test the reliability of modeled values to adequately represent absolute values and spatial variability in WR of total BC and of individual cation within a large area and for many sites is important. In the present study, the PROFILE model was used to estimate WRs for 21 forested catchments on the Canadian Shield of Quebec. This model was chosen because of its flexibility and availability and also because it is a component of the SAFE model which can be used afterwards to provide a dynamic modeling of forest soils responses to management scenarios or to changes in acid deposition as was done, for example, for the UK (Langan et al., 2009). The modeled WRs obtained with PROFILE were compared with independent variables such as the lake's BC concentrations and net catchment BC exports. Such comparisons with a relatively high number of sites provides a robust approach to test the capability of the PROFILE model to yield WRs and take into account spatial variability in soil mineralogy, temperature and precipitation within the large study area.

\section{Methods}

\subsection{Sites description}

The 21 catchments of the Quebec lake network are located on the Canadian Shield within a $\sim 90000 \mathrm{~km}^{2}$ area defined as a $150 \mathrm{~km}$ wide strip, parallel to the St. Lawrence River, 


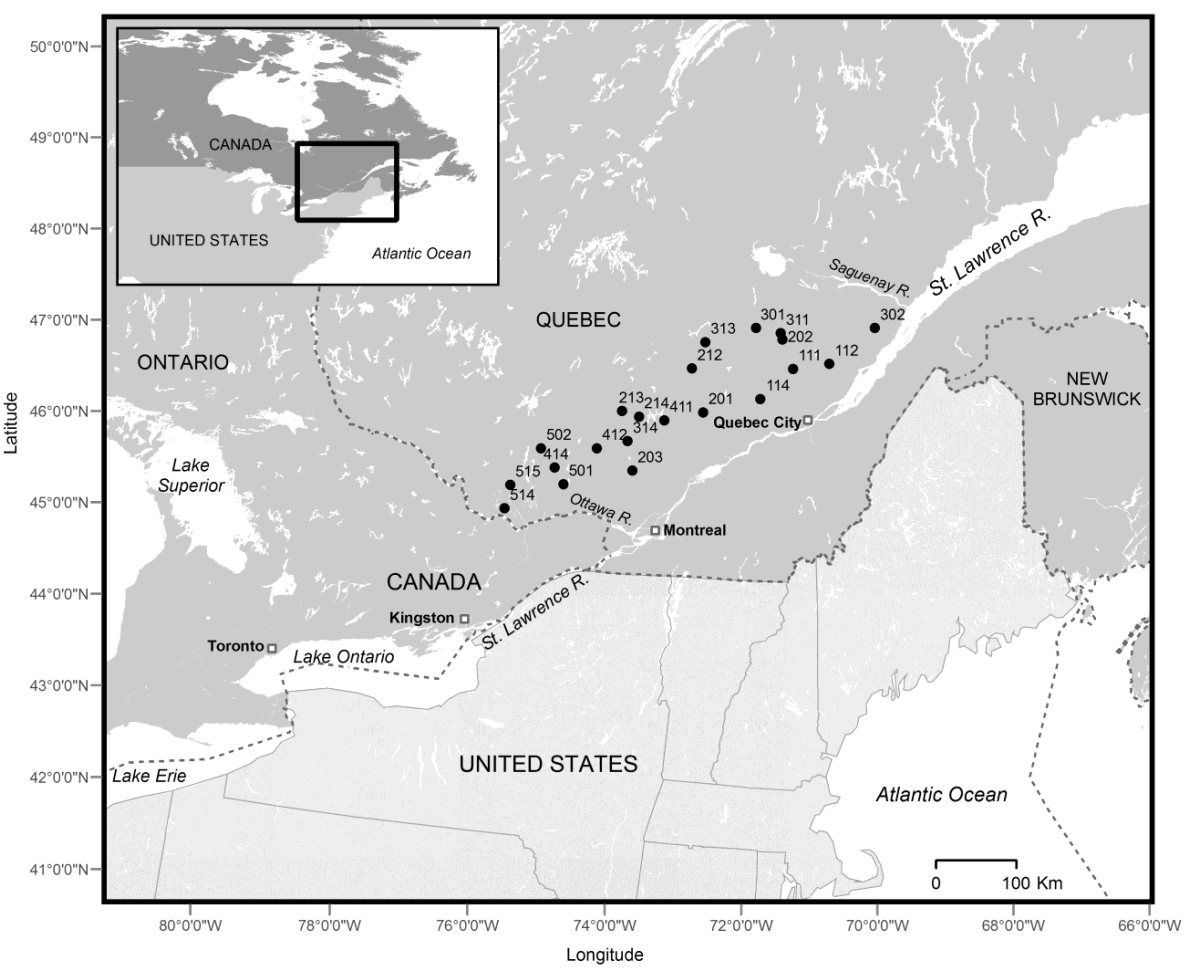

Fig. 1. Locations of the 21 studied catchments in the province of Québec.

between the city of Ottawa and the Saguenay River (Fig. 1). In this region, the Canadian Shield is composed of bedrocks formed during the Precambrian Eon, which consists mainly of igneous (granite, syenite, anorthosite) and metamorphic (gneiss, granitic gneiss, paragneiss) rocks (Lachance et al., 1985). The catchments were selected to ensure they are forested and free of major human activity and also of peat bogs, to minimize the influence of organic acids. The catchments are all characterized by a first order lake with a welldefined stream outflow. The vegetation ranges from forests dominated by sugar maple (Acer saccharum Marsh.) in the southwest, to balsam fir (Abies balsamea L.) or black spruce (Picea mariana Mill.) in the northeast of the study area. The soils in the watersheds are mainly orthic humo-ferric or ferro-humic podzols. These types of soils are typically shallow, covered with a humus layer of $7-10 \mathrm{~cm}$ followed by a thin (sometime discontinuous) illuviated Ae horizon and with a B horizon average thickness of $49.7 \mathrm{~cm}$ that is quite constant among the catchments as illustrated by the low standard error of $2.4 \mathrm{~cm}$ (Table 1). The thickness of the till deposit is not exactly known for each catchment but it typically reaches $2-4 \mathrm{~m}$ (including the developed soil profile) at midslope. The $\mathrm{C}$ horizon that gets rapidly heavily compacted with depth, lies on the impermeable rock of the Canadian shield. As a result, ground water losses can be neglected and all the water leaving the catchment (except for evapotranspiration) is assumed to be evacuated by the stream output.
More details on the Quebec lake network can be found in Houle et al. (2004, 2006).

\subsection{Soil sampling}

In the summer and fall of 2001 and 2002, three soil pits were dug to a depth of $1 \mathrm{~m}$ within each catchment. The soil pits were dug approximately $50 \mathrm{~m}$ from the lake shore and were evenly distributed around the lake perimeter. All soil horizons with a thickness greater than $4 \mathrm{~cm}$ were sampled individually, the maximum depth of the rooting zone was measured, and a field estimate of percent volume of large stones was made based on diagrams in the Munsell book. Core samples were taken from each main soil horizon (diameter: $53 \mathrm{~mm}$, length: $60 \mathrm{~mm}$ ) to determine bulk density. Samples were air dried and sieved to $2 \mathrm{~mm}$ (see Houle et al., 1997 for more details on soil sampling). Prior to analysis, the distinct B horizons sampled (typically 3 to 4 ) from the soil pits were pooled together, taking into account horizon thickness and bulk density of each horizon. It is assumed that the sum of the B horizons contributes for the vast majority of the weathering of the whole soil profile for those podzolic soils. This assumption is based, as mentioned above, on the fact that the till deposit is relatively shallow for these types of catchment. In addition, the soil solution $\mathrm{pH}$, as observed in intensively monitored calibrated forested catchment in Quebec (Houle et al., 1997; Duchesne and Houle, 2006, 2008), is often one order of magnitude (one $\mathrm{pH}$ unit) higher in the $\mathrm{C}$ horizon than 
Table 1. Catchment and soil charactheristisc for the 21 sites studied. The SE for a given element of a given lake is based on 3 soil profiles per catchment.

\begin{tabular}{|c|c|c|c|c|c|c|c|c|c|c|c|c|}
\hline \multirow[t]{2}{*}{ Lake } & \multicolumn{5}{|c|}{ Catchment and lake variables } & \multicolumn{2}{|c|}{ Climatic variables } & \multicolumn{5}{|c|}{ Soil variables } \\
\hline & $\begin{array}{l}\text { Alt. } \\
(\mathrm{m})\end{array}$ & $\begin{array}{l}\text { Latit } \\
\left({ }^{\circ}\right)\end{array}$ & $\begin{array}{c}\text { Longit } \\
\left(^{\circ}\right)\end{array}$ & $\begin{array}{r}\text { Lake area } \\
\text { (ha) }\end{array}$ & $\begin{array}{r}\text { Catchment } \\
\text { area (ha) }\end{array}$ & $\begin{array}{r}\text { Air temp } \\
\left({ }^{\circ} \mathrm{C}\right)\end{array}$ & $\begin{array}{l}\text { Precip. } \\
(\mathrm{mm})\end{array}$ & $\begin{array}{c}\text { B horizon } \\
\text { thickness }(\mathrm{cm})\end{array}$ & $\begin{array}{l}\text { Soil temp } \\
\quad\left({ }^{\circ} \mathrm{C}\right)\end{array}$ & $\begin{array}{c}\text { Soil water } \\
(\%)\end{array}$ & $\mathrm{pH}$ & $\begin{array}{c}\text { Specific area } \\
\left(\mathrm{m}^{2} \mathrm{~m}^{-3}\right)\end{array}$ \\
\hline 112 & 975 & 47.47 & -70.98 & 11.2 & 88.2 & -1.02 & 1434 & 51 & 2.81 & 21.6 & 5.02 & $7.90 \mathrm{E}+05$ \\
\hline 113 & 671 & 47.37 & -71.67 & 25.2 & 100.2 & 0.89 & 1602 & 39 & 8.22 & 23.1 & 4.85 & $9.93 \mathrm{E}+05$ \\
\hline 114 & 366 & 47.04 & -72.08 & 9.2 & 80.2 & 2.74 & 1327 & 55 & 4.74 & 25.0 & 5.17 & $9.27 \mathrm{E}+06$ \\
\hline 201 & 320 & 46.86 & -73.00 & 17.2 & 42.2 & 3.02 & 1074 & 67 & 5.27 & 24.4 & 4.72 & $1.33 \mathrm{e}+06$ \\
\hline 202 & 549 & 47.72 & -71.77 & 8.2 & 81.2 & 1.54 & 1356 & 45 & 6.88 & 26.1 & 5.22 & $1.07 \mathrm{E}+06$ \\
\hline 203 & 533 & 46.15 & -74.08 & 8.2 & 78.2 & 3.44 & 1299 & 56 & 4.88 & 21.3 & 5.53 & $9.50 \mathrm{E}+05$ \\
\hline 212 & 396 & 47.34 & -73.23 & 48.2 & 249.2 & 2.5 & 1058 & 42 & 5.67 & 24.6 & 4.61 & $1.48 \mathrm{E}+06$ \\
\hline 213 & 594 & 46.81 & -74.33 & 15.2 & 112.2 & 1.61 & 962 & 50 & 4.59 & 26.9 & 4.63 & $9.60 \mathrm{E}+05$ \\
\hline 214 & 472 & 46.76 & -74.04 & 21.2 & 168.2 & 2.78 & 964 & 39 & 5.82 & 15.9 & 4.67 & $1.09 \mathrm{E}+06$ \\
\hline 301 & 412 & 47.83 & -72.22 & 9.2 & 51.2 & 2.39 & 1135 & 43 & 4.44 & 25.1 & 4.86 & $1.04 \mathrm{E}+06$ \\
\hline 302 & 625 & 47.88 & -70.24 & 9.2 & 93.2 & 0.69 & 1165 & 33 & 3.33 & 25.1 & 5.25 & $6.97 \mathrm{E}+05$ \\
\hline 311 & 533 & 47.79 & -71.81 & 11.2 & 120.2 & 1.62 & 1202 & 32 & 4.34 & 21.2 & 4.88 & $1.11 \mathrm{E}+06$ \\
\hline 313 & 305 & 47.64 & -73.04 & 8.2 & 90.2 & 2.59 & 1187 & 48 & 4.42 & 21.2 & 5.36 & $1.30 \mathrm{E}+06$ \\
\hline 314 & 457 & 46.48 & -74.20 & 14.2 & 59.2 & 3.12 & 1124 & 36 & 5.57 & 21.0 & 4.80 & $1.12 \mathrm{E}+06$ \\
\hline 411 & 366 & 46.75 & -73.38 & 12 & 79.0 & 3.7 & 1119 & 47 & 6.63 & 20.8 & 4.86 & $1.28 \mathrm{E}+06$ \\
\hline 412 & 366 & 46.37 & -74.68 & 30.2 & 218.2 & 3.98 & 1064 & 55 & 5.64 & 20.8 & 4.96 & $1.20 \mathrm{E}+06$ \\
\hline 414 & 412 & 46.11 & -75.33 & 6.2 & 38.2 & 3.66 & 1072 & 59 & 6.17 & 20.7 & 4.78 & $1.09 \mathrm{E}+06$ \\
\hline 501 & 244 & 45.93 & -75.17 & 46.2 & 129.2 & 4.68 & 1073 & 50 & 5.24 & 19.4 & 4.57 & $1.27 \mathrm{E}+06$ \\
\hline 502 & 213 & 46.31 & -75.58 & 34.2 & 172.2 & 5.13 & 988 & 64 & 6.67 & 19.9 & 4.46 & $1.23 \mathrm{E}+06$ \\
\hline 514 & 244 & 45.60 & -76.07 & 11.2 & 61.2 & 5.02 & 994 & 73 & 5.09 & 19.1 & 4.72 & $1.29 \mathrm{E}+06$ \\
\hline 515 & 335 & 45.84 & -75.86 & 7.0 & 68.0 & 4.52 & 1221 & 59 & 5.55 & 20.8 & 4.62 & $1.64 \mathrm{E}+06$ \\
\hline Average & $\begin{array}{l}447 \\
(37)\end{array}$ & & & $\begin{array}{l}17.3 \\
(2.7)\end{array}$ & $\begin{array}{l}103.8 \\
(11.9)\end{array}$ & $\begin{array}{r}2.79 \\
(0.33)\end{array}$ & $\begin{array}{r}1163 \\
(35)\end{array}$ & $\begin{array}{l}48.8 \\
(2.3)\end{array}$ & $\begin{array}{c}5.33 \\
(0.26)\end{array}$ & $\begin{array}{l}22.1 \\
(0.6)\end{array}$ & $\begin{array}{c}4.88 \\
(0.06)\end{array}$ & $\begin{array}{c}1.14 \mathrm{E}+06 \\
(4.72 \mathrm{E}+04)\end{array}$ \\
\hline
\end{tabular}

in the B horizon thus considerably slowing down the weathering reactions.

\subsection{Soil analyses}

Soil texture was determined on $\mathrm{H}_{2} \mathrm{O}_{2}$ pretreated samples by wet sieving, followed by sedimentation analysis using an Analysette 22 COMPACT (Fritsch $\mathrm{GmbH}$ ) laser sizer. Sodium hexametaphosphate was used to disperse the silt + clay samples before analysis. Bulk chemistry (or elemental composition) of the samples was determined on 32mm-diameter fused beads prepared from a 1:5 soil-lithium tetraborate mixture using an automated X-ray fluorescence spectrometer system (Philips PW2440 4kW) with a Rhodium $60-\mathrm{kV}$ end window X-ray tube. Mineralogy of the clay fraction $(<2 \mu \mathrm{m})$ was determined by X-ray diffraction on $\mathrm{Mg}$ and K-saturated samples separated from the sedimentation analysis and centrifugation. Oriented samples were analyzed at $25^{\circ} \mathrm{C}$, after glycolation and heating treatments $\left(550^{\circ} \mathrm{C}\right)$, using $\mathrm{CuK} \alpha$ radiation. Powders produced for X-ray fluorescence were also mounted as non-oriented slides and analyzed by X-ray diffraction.

Results of the elemental analysis were used to assign elements to their respective minerals using the UPPSALA model (Sverdrup and Warfvinge, 1992). UPPSALA is a normative back-calculation model developed for the reconstruction of empirical mineralogy using bulk chemistry. It is based on assumptions of the stoichiometric composition of the minerals in soils of granitic origin (Precambrian Shield of Sweden). The minerals are grouped into assemblies of minerals with similar composition and dissolution rates. In UPPSALA, chlorite is composed of trioctahedral chlorite, primary illite, trioctahedral vermiculite of primary type, and biotite, whereas epidote includes all epidotes and pyroxenes. Consistency between semi-quantitative X-ray diffraction results and UPPSALA norms was verified as a form of model validation.

\subsection{Monthly hydro-climatic variables, soil water contents and soil temperatures}

Average monthly precipitation and temperature were generated for each catchment with the BioSIM model (Régnière, 1996; Régnière and St-Amant, 2007). BioSIM was originally developed to simulate insect development at the regional scale as a function of time-series of weather data. It operates by matching the geo-referenced sources of weather data (120 monitoring stations including the last 30 years of data) to the specified location, and then adjusts the selected sources of weather data to the specified latitude, longitude, elevation, slope, and aspect. The correlation between estimated and measured values is generally over $98 \%$ (Régnière and Bolstad, 1994). The hydroclimatic data generated for each catchment in this study are robust as they are averages calculated from four climatological stations. 
The monthly hydroclimatic variables were then used to simulate soil moisture and soil temperature with the models FORHYM and FORSTEM, respectively (Arp and Yin, 1992; Yin and Arp, 1993; Houle et al., 2002). A different model was built for each soil pits taking into account its specific characteristics, i.e., horizon depth and thickness, bulk density, texture and rooting depth. These models were used to generate water fluxes within the soil and at the stream outlet, which, when combined with the measurement of element concentrations, can yield element fluxes (Houle et al., 1997; Duchesne and Houle, 2006, 2008). Average annual temperature and precipitation values from 1997 to 2002 were used for the purpose of comparison with lake BC concentrations and catchment exports, which were measured during this period (see below).

\subsection{Simulation of weathering rates with PROFILE}

Release rates of $\mathrm{BC}$ via soil mineral weathering were estimated using the PROFILE v5.0 model (Becker, 1999). It is a steady-state model that calculates the soil solution chemical composition based on a complex mathematical and schematic description of a soil. Although many approaches or models have been developed to address weathering reactions at large (Brantley and White, 2009), the PROFILE model has been specifically built for calculating weathering rates for relatively thin forest soils which are water conductive and for which the erosional component of weathering is negligible. The basic equations underlying the model were first described in Sverdrup and Warfvinge (1988). An insightful critical review of the theory behind the model as well as of the principal equations was later provided by Hodson et al. (1997). The model has been developed to estimate WRs for granitic soils with relatively low weathering potential in Sweden (e.g., Sverdrup and Warfvinge, 1993, 1995). The model generates yearly WRs for $\mathrm{Ca}, \mathrm{Mg}, \mathrm{K}, \mathrm{Na}, \mathrm{P}, \mathrm{Al}$ and $\mathrm{Si}$. Input variables for which PROFILE is sensitive are mineralogy, specific surface area, soil water content, and soil temperature. These input variables have significant impacts on the model output because they determine the amount and type of weatherable surfaces available as well as the kinetics of the weathering reactions.

The dissolution rates of 14 individual minerals present in a given soil horizon calculated taken into account soil temperature and soil solution composition are summed to yield the weathering rate for that given horizon. Weathering rate on a surface basis is then calculated taking into account, the relative proportions of the 14 minerals, soil surface area, and the proportion of the exposed surface area which is wetted (Hodson et al., 1997):

$R_{\mathrm{w}}=\sum_{j=1}^{\text {minerals }} r_{j} A_{W} x_{j} \theta Z$

where
$R_{\mathrm{W}}=$ weathering rate of the soil horizon $\left(\mathrm{keq} \mathrm{m}^{-2} \mathrm{~s}^{-1}\right)$; $r_{j}=$ dissolution rate of mineral $j\left(\mathrm{keq} \mathrm{m}^{-3} \mathrm{~s}^{-1}\right)$;

$A_{W}=$ total exposed mineral surface area $\left(\mathrm{m}_{\text {mineral }}^{2} \mathrm{~m}_{\text {soil }}^{-3}\right)$;

$x_{j}=$ the surface area fraction of soil mineral $j\left(\mathrm{~m}^{2} \mathrm{~m}^{-2}\right)$;

$\theta=$ soil moisture saturation $\left(\mathrm{m}^{3} \mathrm{~m}^{-3}\right)$;

$Z=$ soil layer thickness $(\mathrm{m})$.

The mineralogy calculated from UPPSALA was used as input to PROFILE and as mentioned above, consistency between X-ray diffraction results and UPPSALA norms were checked as a form of model validation. Other model inputs included, annual precipitation amounts and yearly averages of soil moisture content and temperature. Specific surface area was calculated from an algorithm developed by Jönsson et al. (1995) from measured grain size distribution, dry bulk density, and coarse fragments. Partial pressure of $\mathrm{CO}_{2}$ was estimated following the values used in Warfinge and Sverdrup (1995). A value of $5 \mathrm{mg} \mathrm{l}^{-1}$ was used for dissolved organic carbon (DOC) concentration in the soil solution. This value was based on the results of soil solution chemistry in the B horizons originating from three calibrated catchments for which detailed measurements are available (Houle et al., 1997; Duchesne and Houle, 2006, 2008). The model output sensibility to DOC variations was analysed and within the range of DOC concentrations that can be encountered in such mineral soils, the effect on weathering rates estimation was negligible (data not shown). Precipitation amounts were obtained from BioSIM, whereas soil moisture and temperature were respectively generated from the FORHYM and FORSTEM models.

\subsection{Comparison of the modeled $\mathrm{BC}$ weathering rates with lake $\mathrm{BC}$ concentrations and estimated net catchment $B C$ exports}

The PROFILE BC WRs were first compared with the lake BC concentrations taken from Houle et al. (2006). Also, estimates of annual catchment $\mathrm{BC}$ exports were obtained by multiplying $\mathrm{BC}$ lake concentrations by the estimated annual runoff obtained from the FORHYM model for each of the 21 catchments divided by the terrestrial area of the catchments. The FORHYM model used to generate streamflow and soil moisture have been validated on three watersheds in Quebec similar to those used in this study (Houle et al., 2002, 2011) and at other sites (Arp and Yin, 1992) and it has been shown that this model reproduces with great accuracy the variables cited above, especially when annual estimates are considered. Despite the error that could be associated with annual runoff estimation, it should be noted that the greatest source of variation between watershed's BC exportations is not the range in runoff but the range in cation concentration in the lakes. So the small errors that could be associated with the runoff estimations have almost no impacts on our correlation analysis. This is why PROFILE estimated weathering rates of $\mathrm{Ca}$ and $\mathrm{Mg}$ correlate well with both, $\mathrm{BC}$ lake concentrations and $\mathrm{BC}$ watershed exportations (see below). 
Table 2. Total element concentrations (weight \%) of the B horizons for each catchment. Standard errors are shown in parentheses.

\begin{tabular}{|c|c|c|c|c|c|c|c|c|c|c|c|}
\hline Lake & $\mathrm{SiO}_{2}$ & $\mathrm{TiO}_{2}$ & $\mathrm{Al}_{2} \mathrm{O}_{3}$ & $\mathrm{Fe}_{2} \mathrm{O}_{3}$ & $\mathrm{MnO}$ & $\mathrm{MgO}$ & $\mathrm{CaO}$ & $\mathrm{Na}_{2} \mathrm{O}$ & $\mathrm{K}_{2} \mathrm{O}$ & $\mathrm{P}_{2} \mathrm{O}_{5}$ & $\sum_{\text {metals }}$ Trace \\
\hline 112 & $63.83(2.24)$ & $1.39(0.16)$ & $15.80(0.40)$ & 7.43 (1.39) & $0.09(0.02)$ & $1.02(0.28)$ & $3.11(0.37)$ & $3.14(0.08)$ & $3.64(0.24)$ & $0.54(0.14)$ & $0.01(0.01)$ \\
\hline 113 & $65.77(2.92)$ & $1.47(0.35)$ & $15.50(0.79)$ & $6.47(3.85)$ & $0.09(0.02)$ & $0.91(0.05)$ & $2.61(0.20)$ & $3.17(0.17)$ & $3.52(0.20)$ & $0.42(0.07)$ & $0.11(0.03)$ \\
\hline 114 & $70.53(0.74)$ & $0.66(0.16)$ & $14.30(0.26)$ & $4.50(0.88)$ & $0.07(0.01)$ & $0.79(0.13)$ & $2.48(0.27)$ & $3.21(0.11)$ & $3.26(0.33)$ & $0.18(0.04)$ & $0.01(0.00)$ \\
\hline 201 & $64.17(0.38)$ & $1.03(0.09)$ & $16.13(0.45)$ & $6.98(0.40)$ & $0.10(0.01)$ & $1.51(0.06)$ & $3.21(0.06)$ & $3.66(0.14)$ & $2.91(0.10)$ & $0.23(0.02)$ & $0.07(0.00)$ \\
\hline 202 & $66.23(4.27)$ & $0.98(0.28)$ & $15.70(1.55)$ & $6.05(2.88)$ & $0.08(0.01)$ & $1.00(0.20)$ & $2.89(0.35)$ & $3.36(0.16)$ & $3.24(0.36)$ & $0.45(0.31)$ & $0.01(0.00)$ \\
\hline 203 & $70.30(0.99)$ & $0.99(0.03)$ & $14.50(1.41)$ & $5.88(0.15)$ & $0.15(0.10)$ & $1.53(0.18)$ & $2.65(0.24)$ & $1.15(0.04)$ & $2.52(0.01)$ & $0.24(0.09)$ & $0.08(0.01)$ \\
\hline 212 & $63.00(0.36)$ & $1.24(0.02)$ & $15.63(1.40)$ & $7.29(0.47)$ & $0.11(0.02)$ & $2.12(0.47)$ & $3.84(0.77)$ & $3.53(0.04)$ & & & \\
\hline 213 & $65.30(2.26)$ & $0.92(0.03)$ & $16.90(1.85)$ & $6.64(0.33)$ & $0.08(0.00)$ & $1.22(0.12)$ & $2.45(0.12)$ & $3.24(0.05)$ & $2.93(0.18)$ & $0.23(0.02)$ & $0.07(0.01)$ \\
\hline 214 & $68.87(2.33)$ & $0.83(0.06)$ & $14.57(1.15)$ & $5.63(0.78)$ & $0.08(0.01)$ & $1.46(0.14)$ & $2.59(0.30)$ & & & $0.23(0.06)$ & $0.01(0.00)$ \\
\hline 301 & $65.40(5.29)$ & $0.86(0.06)$ & $17.43(4.22)$ & $6.21(1.92)$ & $0.08(0.01)$ & $0.98(0.02)$ & $2.52(0.33)$ & $3.20(0.36)$ & $3.05(0.28)$ & $0.28(0.05)$ & $0.01(0.00)$ \\
\hline 302 & $62.60(1.90)$ & $1.15(0.03)$ & $17.17(1.39)$ & & & & & & & & $0.08(0.02)$ \\
\hline 311 & $66.35(0.21)$ & $0.97(0.05)$ & $16.15(0.21)$ & $5.82(0.08)$ & $0.07(0.00)$ & $1.09(0.08)$ & $2.64(0.01)$ & $3.38(0.07)$ & $3.26(0.09)$ & $0.27(0.00)$ & $0.01(0.00)$ \\
\hline 313 & $63.20(0.87)$ & $1.13(0.06)$ & $16.47(0.06)$ & $7.22(0.41)$ & $0.10(0.00)$ & $1.59(0.21)$ & $3.51(0.25)$ & $3.60(0.02)$ & $2.76(0.07)$ & $0.34(0.05)$ & $0.08(0.00)$ \\
\hline 314 & $67.53(0.70)$ & $1.03(0.10)$ & $13.93(1.15)$ & $6.90(0.68)$ & $0.08(0.02)$ & $1.41(0.24)$ & $2.62(0.31)$ & $2.82(0.23)$ & $3.42(0.64)$ & $0.17(0.03)$ & $0.07(0.01)$ \\
\hline 411 & $66.50(1.35)$ & $1.03(0.21)$ & $14.97(0.58)$ & $6.66(0.85)$ & $0.11(0.02)$ & $1.25(0.07)$ & $3.06(0.03)$ & $3.33(0.08)$ & $2.76(0.06)$ & $0.27(0.07)$ & $0.09(0.02)$ \\
\hline 412 & $65.17(0.81)$ & $0.97(0.13)$ & $15.97(0.21)$ & $7.07(0.48)$ & $0.10(0.02)$ & $1.96(0.11)$ & $2.77(0.06)$ & $2.74(0.13)$ & $2.91(0.21)$ & $0.29(0.10)$ & $0.06(0.01)$ \\
\hline 414 & $67.13(1.55)$ & $0.99(0.14)$ & $15.20(0.66)$ & $6.88(0.79)$ & $0.09(0.01)$ & $1.93(0.27)$ & $3.34(0.19)$ & $1.36(0.06)$ & $2.78(0.24)$ & $0.24(0.06)$ & $0.08(0.01)$ \\
\hline 501 & $71.35(1.48)$ & $0.78(0.16)$ & $13.60(0.14)$ & $5.00(0.84)$ & $0.12(0.06)$ & $1.60(0.16)$ & $3.32(0.21)$ & $1.28(0.00)$ & $2.65(0.04)$ & $0.22(0.14)$ & $0.07(0.01)$ \\
\hline 502 & $67.90(2.35)$ & $0.85(0.04)$ & $14.47(1.07)$ & $6.78(0.77)$ & $0.09(0.01)$ & $2.34(0.26)$ & $3.61(0.38)$ & $1.30(0.15)$ & $2.41(0.21)$ & $0.25(0.07)$ & $0.07(0.01)$ \\
\hline 514 & $65.23(2.82)$ & $0.92(0.08)$ & $15.87(0.81)$ & $7.17(1.82)$ & $0.11(0.03)$ & $2.00(0.42)$ & $4.10(0.64)$ & $1.41(0.12)$ & $2.82(0.21)$ & $0.27(0.08)$ & $0.08(0.02)$ \\
\hline 515 & $68.17(0.40)$ & $0.80(0.06)$ & $14.73(0.40)$ & $5.78(0.46)$ & $0.10(0.01)$ & $2.33(0.19)$ & $3.67(0.18)$ & $1.26(0.05)$ & $2.70(0.06)$ & $0.39(0.19)$ & $0.07(0.01)$ \\
\hline Average & $66.41(2.48)$ & $1.00(0.20)$ & $15.48(1.05)$ & $6.50(0.87)$ & $0.09(0.02)$ & $1.50(0.47)$ & $3.04(0.49)$ & $2.68(0.93)$ & $2.96(0.32)$ & $0.29(0.09)$ & $0.06(0.03)$ \\
\hline
\end{tabular}

This approach to estimate $\mathrm{BC}$ exportation also assumes that $\mathrm{BC}$ concentrations at the center of the lake are similar to $\mathrm{BC}$ concentrations exported at the stream output. In fact, contrary to nitrate or phosphate, which are limiting nutrient in these oligotrophic lakes of the Canadian Shield, BC cation are generally far in excess of nutritional needs for plankton or macrophytes and their behaviour is relatively conservative in lakes. This was verified for the lake Laflamme, one of the network lake which is intensively monitored for element budget on a weekly basis at the stream output and occasionally at the center of the lake (Duchesne and Houle, 2008). The root square between mean annual values of $\mathrm{Ca}$ measured at the center of the lake and at the stream output was $0.91(n=25)$ and the average difference between both was $9.6 \%$ (data not shown).

The atmospheric deposition fluxes of BC (Ouimet and Duchesne, 2009) were then subtracted from the export values to yield net exportations that correspond to WRs. This method assumes steady state conditions for BC cycling in the catchments, i.e., no accumulation in (or losses from) the soil exchangeable pools and/or in the vegetation end-member.

\section{Results and discussion}

\subsection{Soil elemental chemistry and mineralogy}

The soil elemental compositions of the whole B horizon are presented in Table 2. These are typical of soils developed in such lithologies with large amounts of $\mathrm{SiO}_{2}, \mathrm{Al}_{2} \mathrm{O}_{3}$ and
$\mathrm{Fe}_{2} \mathrm{O}_{3}$ and low amounts of $\mathrm{CaO}, \mathrm{MgO}, \mathrm{K}_{2} \mathrm{O}$ and $\mathrm{Na}_{2} \mathrm{O}$. Overall, $\mathrm{SiO}_{2}$ and $\mathrm{Al}_{2} \mathrm{O}_{3}$ contents, the two largest constituents in the soils, vary less across the sites than the other constituents. Magnesium varies the most amongst the alkali earth elements, followed by $\mathrm{Ca}$ and then $\mathrm{Na}$ and $\mathrm{K}$. Phosphorus varies equally to $\mathrm{MgO}$. Metals, $\mathrm{Mn}$ and $\mathrm{Ti}$ also suggest significant variability across the 21 sites.

The normative mineralogy produced from the UPPSALA model is shown for each catchment in Table 3. For a given catchment, the normative mineralogy calculated from three soil profiles show very small variation as illustrated by the small standard errors. Quartz, albite, K-feldspars, hornblende, plagioclase and muscovite form the bulk of the soils with average contents of $32,19,17,13,10$ and $2.8 \%$, respectively. Other minerals such as pyroxene, garnet, biotite, vermiculite and apatite form on average between 0.7 to $1.9 \%$ of the soils, whereas chlorite, vermiculite and kaolinite represent less than $0.5 \%$ of the bulk soils. The norm did not yield epidote in any of the sites. The overall variability of quartz, $\mathrm{K}$-feldspars, plagioclase, pyroxene, apatite and hornblende is low compared to the other minerals. Amongst the minerals that vary the most across the sites are chlorite, calcite, biotite and kaolinite, while muscovite, vermiculite, garnet and albite varied moderately.

On the one hand, there is a general trend with the data set which shows that sites with high $\mathrm{CaO}$ contents have high hornblende and calcite contents. These soils also show lower plagioclase and albite contents because they have lower $\mathrm{Na}_{2} \mathrm{O}$ contents and higher $\mathrm{mCa} / \mathrm{mNa}$ ratios. The model therefore produced hornblende and calcite first, followed by 


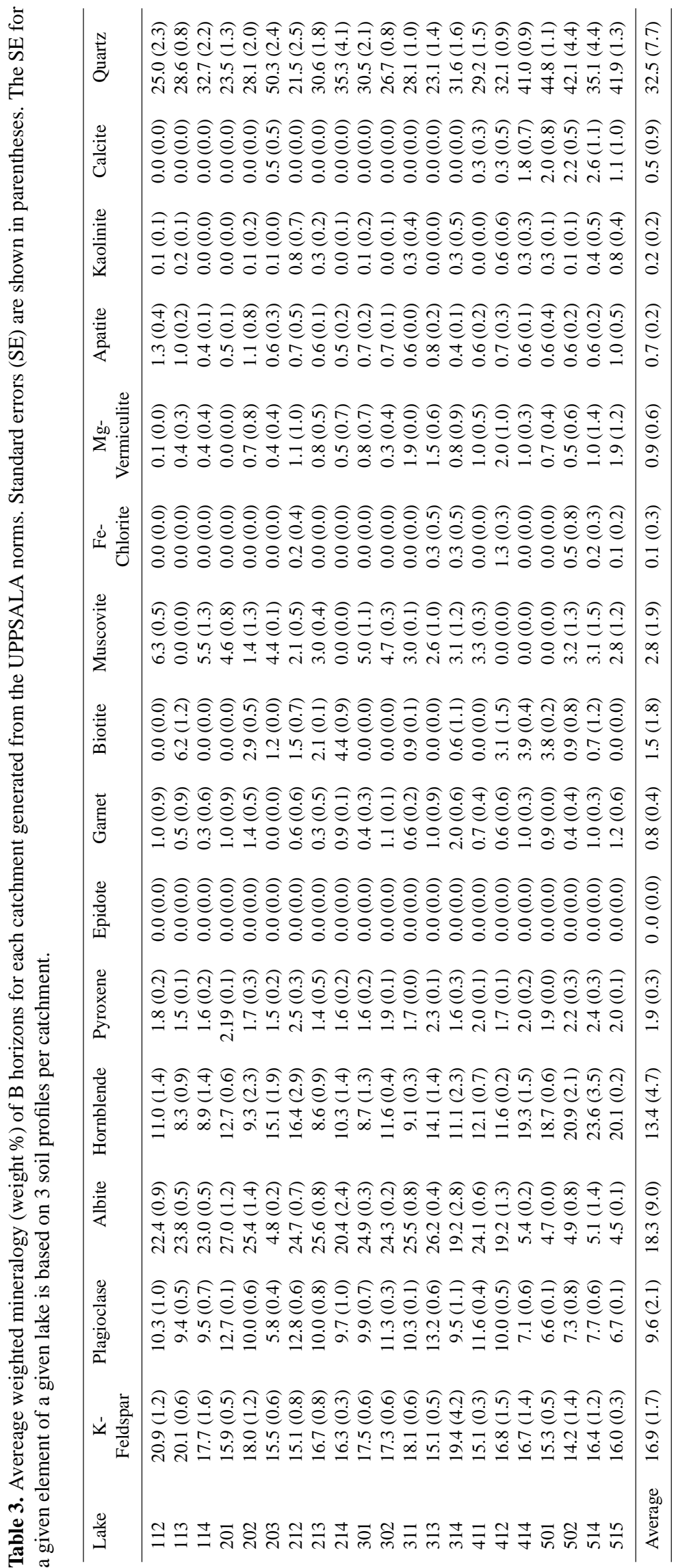


plagioclase using the remaining $\mathrm{Ca}$, and finally albite using the remaining Na. This trend can be associated to the southwestern part of the study area which is known for the presence of marble from the metamorphosis of limestone and dolomite. The tills therefore have a mixed petrography acquired through the glacial transport of the felsic rocks and marbles that abound in the surrounding area (Houle et al., 2004). On the other hand, the arbitrary minerals such as apatite, pyroxene, garnet, and phyllosilicates do not show clear regional patterns, suggesting that these are governed by subtle changes in bedrock composition at the local scale and/or pedogenesis.

Despite their high Ca levels, the UPPSALA norms did not yield epidote, an easily weathered Ca-rich mineral (Pettijohn, 1941) that is often formed from the hydration of hornblende by a hydrothermal fluid once the granitic rocks are emplaced. The UPPSALA norms failed to account for this alteration reaction because $\mathrm{Ca}$ is first allocated to hornblende/calcite/plagioclase and then to epidote. The allocation of $\mathrm{Ca}$ to hornblende also tends to decrease the normative phyllosilicate (e.g., Fe-chlorite and $\mathrm{Mg}$-vermiculite) abundances because this makes the allocation of $\mathrm{Mg}$ to hornblende priority relative to phyllosilicates.

\subsection{Modeled weathering rates}

The average WR of $\mathrm{BC}+\mathrm{Na}$ simulated by PROFILE for the 21 watersheds was $1.71 \mathrm{kmol}_{\mathrm{c}} \mathrm{ha}^{-1} \mathrm{yr}^{-1}$ and ranged from $0.58 \mathrm{kmol}_{\mathrm{c}} \mathrm{ha}^{-1} \mathrm{yr}^{-1}$ to $4.46 \mathrm{kmol}_{\mathrm{c}} \mathrm{ha}^{-1} \mathrm{yr}^{-1}$ (Table 4). Calcium was clearly the dominant contributor to the total amount of $\mathrm{BC}+\mathrm{Na}$ released (average of $0.91 \mathrm{kmol}_{\mathrm{C}} \mathrm{ha}^{-1} \mathrm{yr}^{-1}$ ) followed by $\mathrm{Mg}, \mathrm{Na}$ and $\mathrm{K}$ with respective values of $0.39,0.28$ and $0.12 \mathrm{kmol}_{\mathrm{c}} \mathrm{ha}^{-1} \mathrm{yr}^{-1}$ (Table 4). The WRs of total $\mathrm{BC}+\mathrm{Na}$ varied spatially, being higher in the southwest of the study area and decreasing toward the northeast, as illustrated by the significant correlations (data not shown) with latitude $(r=-0.72)$ and longitude $(r=-0.77)$. The decrease in WRs from the southwest to the northeast may therefore be partly caused by decreasing average annual temperature along the latitudinal gradient, given the influence of temperature on WRs (White et al., 1999). This is also possibly due to the spatial variations in the petrography of the tills within the studied area, which is also reflected in the mineralogical composition of the $\mathrm{B}$ horizons (Table 3). To support this further, the $\mathrm{Ca}$ and Mg WRs for the entire 21 catchments are positively correlated to calcite and hornblende contents (Table 5), which are more abundant in the soils of the southwest study area. Conversely, the Na WRs are negatively correlated to hornblende and calcite (Table 5). Also, $\mathrm{Ca}$ and $\mathrm{Mg}$ WRs are negatively correlated to albite contents and (Table 5), which is less abundant in the southwestern soils. The release of $\mathrm{Mg}$ by weathering also seems to be influenced by more subtle local changes in soil mineralogy as both Mg-containing phyllosilicates (i.e., Fe-chlorite and Mg-vermiculite which
Table 4. Weathering rates obtained with the PROFILE model for the 21 individual catchments.

\begin{tabular}{lccc}
\hline \multirow{2}{*}{ Base cation } & \multicolumn{3}{c}{ PROFILE Weathering rates $\left(\mathrm{kmol}_{\mathrm{c}} \mathrm{ha}^{-1} \mathrm{yr}^{-1}\right)$} \\
\cline { 2 - 4 } & Average & $\mathrm{SE}$ & Min-max \\
\hline $\mathrm{Ca}$ & 0.91 & 0.19 & $0.22-3.46$ \\
$\mathrm{Mg}$ & 0.39 & 0.04 & $0.16-0.78$ \\
$\mathrm{~K}$ & 0.12 & 0.01 & $0.05-0.18$ \\
$\mathrm{Na}$ & 0.28 & 0.04 & $0.07-0.65$ \\
\hline$\sum \mathrm{BC}$ & 1.71 & 0.22 & $0.58-4.46$ \\
\hline
\end{tabular}

show not regional trend) are positively correlated to $\mathrm{Mg}$ WRs (Table 5). Muscovite is negatively correlated to K WRs, but biotite is not correlated with $\mathrm{K}$ release. On the one hand, muscovite is a highly recalcitrant mineral to weathering and is not thought to release large quantities of $\mathrm{K}$ to the plants (Wallander, 2000). Also, biotite (or its chlorite/vermiculite intergrades) is often considered a crucial source of $\mathrm{K}$ to plants (Wallander, 2000). In UPPSALA, chlorite is composed of trioctahedral chlorite, primary illite, trioctahedral vermiculite of primary type, and biotite. Finally, a gradient can also be observed in the clay content (and in the specific surface area) which is higher in the southwest than in the northeast portion of the studied area. The coarser grain size fractions (sands) probably do not differ much in bulk chemistry and mineralogy relative to the finer particles (silt and clay) but differences in specific surface area and reactivity to acidic solutions may be large (Stillings and Brantley, 1995).

The sum of the modeled $\mathrm{BC}+\mathrm{Na}$ weathering average values $\left(1.71 \mathrm{kmol}_{\mathrm{c}} \mathrm{ha}^{-1} \mathrm{yr}^{-1}\right)$ and the average net catchment exportation values $\left(1.20 \mathrm{kmol}_{\mathrm{c}} \mathrm{ha}^{-1} \mathrm{yr}^{-1}\right)$ are two to three times higher than previous WRs reported by Ouimet et al. (2006) for the soils of a vast area of the province of Québec (typically lower than $0.5 \mathrm{kmol}_{\mathrm{c}} \mathrm{ha}^{-1} \mathrm{yr}^{-1}$ ). In this latter study, a relationship using soil texture was used to generate soil WRs. It strongly suggests that this relationship was not totally adequate at least for Quebec soils and as a result, Ouimet et al. (2006) probably underestimated WRs. Koseva et al. (2010) recently reported that WRs estimated with PROFILE were seven times higher than WRs estimated from a relationship with soil texture, in good agreement with our results.

\subsection{Comparison of the modeled $\mathrm{BC}$ weathering rates with $B C$ concentrations in lakes and $B C$ watershed exports}

The $\mathrm{BC}+\mathrm{Na}$ WR was significantly correlated $(0.71$, Table 6 and Fig. 2) to the $\mathrm{BC}+\mathrm{Na}$ lake concentration. The $\mathrm{Ca}$ and $\mathrm{Mg}$ lake concentrations were significantly correlated ( $r=0.80$ and 0.64, Table 6) with WRs of $\mathrm{Ca}$ and $\mathrm{Mg}$. Weathering rates of $\mathrm{Ca}$ and $\mathrm{BC}+\mathrm{Na}$ were also significantly 

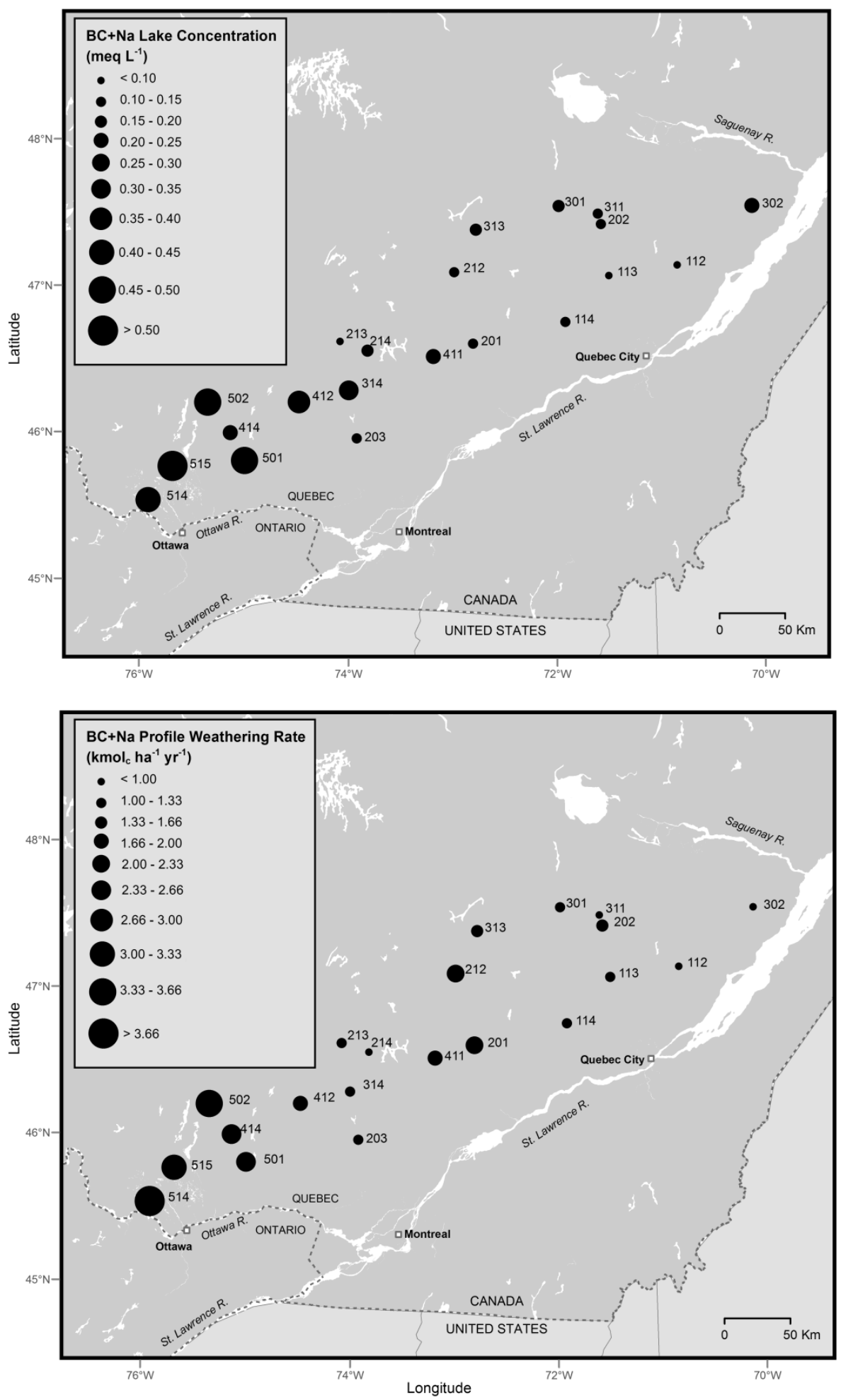

Fig. 2. Spatial variability in the $\mathrm{BC}+\mathrm{Na}$ lake concentrations (upper panel) and in $\mathrm{BC}+\mathrm{Na}$ PROFILE weathering rates (lower panel) for the 21 catchments studied. 
Table 5. Correlation coefficients $(r)$ between ions weathering rates and soil mineralogy. No significant relationship was observed between garnet, biotite, muscovite, $\mathrm{Fe}$-chlorite, $\mathrm{Mg}$-vermiculite, and apatite and any of ions weathering rates.

\begin{tabular}{llllllll}
\hline \multirow{2}{*}{$\begin{array}{l}\text { Weathering } \\
\text { rate }\end{array}$} & \multicolumn{7}{c}{ Mineralogy } \\
\cline { 2 - 7 } & K-Feldspath & Plagioclase & Albite & Hornblende & Pyroxene & Kaolinite & Calcite \\
\hline $\mathrm{BC}+\mathrm{Na}$ & $-0.497^{2}$ & $\mathrm{~ns}^{1}$ & $-0.697^{4}$ & $0.890^{4}$ & $0.664^{3}$ & $0.451^{2}$ & $0.874^{4}$ \\
$\mathrm{Ca}$ & $-0.442^{2}$ & $-0.564^{3}$ & $-0.798^{4}$ & $0.915^{4}$ & $0.593^{3}$ & $\mathrm{~ns}^{1}$ & $0.950^{4}$ \\
$\mathrm{Mg}$ & $-0.550^{3}$ & $\mathrm{~ns}^{1}$ & $-0.682^{4}$ & $0.884^{4}$ & $0.678^{4}$ & $0.615^{3}$ & $0.750^{4}$ \\
$\mathrm{~K}$ & $\mathrm{~ns}^{1}$ & $\mathrm{~ns}^{1}$ & $\mathrm{~ns}^{1}$ & $\mathrm{~ns}^{1}$ & $\mathrm{~ns}^{1}$ & $0.446^{2}$ & $\mathrm{~ns}^{1}$ \\
$\mathrm{Na}$ & $\mathrm{ns}^{1}$ & $0.801^{4}$ & $0.780^{4}$ & $-0.496^{2}$ & $\mathrm{~ns}^{1}$ & $\mathrm{~ns}^{1}$ & $-0.619^{3}$ \\
\hline
\end{tabular}

${ }^{1}$ ns: not significant; ${ }^{2} p<0.05 ;{ }^{3} p<0.01 ;{ }^{4} p<0.001$

Table 6. Correlation coefficients $(r)$ between ions weathering rates estimated with PROFILE and $\mathrm{pH}$, alkalinity, ion concentrations in lakes, and net catchment exportations.

\begin{tabular}{|c|c|c|c|c|}
\hline \multirow{2}{*}{$\begin{array}{l}\text { Weathering } \\
\text { rate }\end{array}$} & \multicolumn{3}{|c|}{ Lake concentrations } & \multirow{2}{*}{$\begin{array}{l}\text { Net catchment } \\
\text { exportations } \\
\mathrm{kmol}_{\mathrm{c}} \mathrm{ha}^{-1} \mathrm{yr}^{-1}\end{array}$} \\
\hline & $\mathrm{pH}$ & $\begin{array}{l}\text { Alkalinity } \\
\left(\mathrm{mg} \mathrm{l}^{-1}\right)\end{array}$ & $\begin{array}{l}\operatorname{ion}(s) \\
\left(\operatorname{meq} 1^{-1}\right)\end{array}$ & \\
\hline $\mathrm{BC}+\mathrm{Na}$ & $0.576^{3}$ & $0.710^{4}$ & $0.708^{4}$ & $0.598^{3}$ \\
\hline $\mathrm{Ca}$ & $0.596^{3}$ & $0.753^{4}$ & $0.804^{4}$ & $0.712^{4}$ \\
\hline $\mathrm{Mg}$ & $0.580^{3}$ & $0.673^{4}$ & $0.636^{3}$ & $0.563^{3}$ \\
\hline $\mathrm{K}$ & $\mathrm{ns}^{1}$ & $\mathrm{~ns}^{1}$ & $\mathrm{~ns}^{1}$ & $\mathrm{~ns}^{1}$ \\
\hline $\mathrm{Na}$ & $\mathrm{ns}^{1}$ & $-0.483^{2}$ & $\mathrm{~ns}^{1}$ & $\mathrm{~ns}^{1}$ \\
\hline
\end{tabular}

${ }^{1}$ ns: not significant; ${ }^{2} p<0.05 ;{ }^{3} p<0.01 ;{ }^{4} p<0.001$

correlated to lake alkalinity ( $r=0.75$ and 0.71 , respectively, Table 6) suggesting that WRs of $\mathrm{BC}+\mathrm{Na}$ in catchments (but particularly $\mathrm{Ca}$ ) is a determinant process for lake alkalinity generation and that in-lake alkalinity generation was not the major factor for determining lake alkalinity for the lakes studied.

Lake concentrations of $\mathrm{Na}$ and $\mathrm{K}$ were not correlated to their respective WRs. The absence of significant correlation for $\mathrm{K}$ was expected since, for most forest ecosystems (Duchesne and Houle, 2008, 2006; Likens et al., 1994), K leaching is usually low in absence of perturbation. This is not the case however for $\mathrm{Na}$ which has a conservative behaviour in forest soils (see the discussion below).

There were significant correlations between the modeled WRs of $\mathrm{Ca}(r=0.71)$ and $\mathrm{Mg}(r=0.56)$ and their respective net catchment exports (Table 6) while net catchment exports of $\mathrm{K}$ and $\mathrm{Na}$ were not correlated to the modeled WRs. There was no significant difference between modeled WR and net catchment export for $\mathrm{Ca}$, whereas WRs of $\mathrm{Mg}, \mathrm{K}, \mathrm{Na}$, and $\mathrm{BC}+\mathrm{Na}$ were significantly higher than the catchment exports (Table 7), although with relatively small absolute differences for $\mathrm{BC}+\mathrm{Na}(42 \%)$ and $\mathrm{Mg}(51 \%)$.
Table 7. Average of weathering rate and net catchment exportation for $\mathrm{BC}+\mathrm{Na}, \mathrm{Ca}, \mathrm{Mg}, \mathrm{K}$ and $\mathrm{Na}$ and results of paired t-test between the two variables $(n=21)$.

\begin{tabular}{lcccr}
\hline & $\begin{array}{c}\text { Weathering } \\
\text { rate } \\
\mathrm{kmol}_{\mathrm{c}} \\
\mathrm{ha}^{-1} \mathrm{yr}^{-1}\end{array}$ & $\begin{array}{c}\text { Net } \\
\text { catchment } \\
\text { exportations } \\
\mathrm{kmol}_{\mathrm{c}} \\
\mathrm{ha}^{-1} \mathrm{yr}^{-1}\end{array}$ & t-test & p-value \\
\hline $\mathrm{BC}+\mathrm{Na}$ & 1.710 & 1.200 & 2.833 & 0.010 \\
$\mathrm{Ca}$ & 0.915 & 0.798 & 0.856 & 0.402 \\
$\mathrm{Mg}$ & 0.389 & 0.258 & 3.523 & 0.002 \\
$\mathrm{~K}$ & 0.125 & 0.018 & 12.97 & $<0.001$ \\
$\mathrm{Na}$ & 0.282 & 0.126 & 4.331 & $<0.001$ \\
\hline
\end{tabular}

Given all the uncertainties in, both the WR and the catchment budget calculations, and the possibility that the catchment BC budgets may not be in steady state, these differences are surprisingly small. For instance, Withfield et al. (2006), when comparing the catchment mass balance method with other methods that estimate weathering rates on a soil profile basis, found that PROFILE WRs were one order of magnitude lower than net catchment exportations for five catchments in Nova Scotia, Canada. The WRs calculated here for the 21 catchments with both methods are one order of magnitude higher than the PROFILE WRs calculated by Withfield et al. (2006) while they are fairly similar to their net catchment exportations values. Our PROFILE WRs values (average of $1.71 \mathrm{kmol}_{\mathrm{c}} \mathrm{ha}^{-1} \mathrm{yr}^{-1}$ ) are also comparable to the average value of $0.8 \mathrm{kmol}_{\mathrm{c}} \mathrm{ha}^{-1} \mathrm{yr}^{-1}$ reported by Ouimet and Duchesne (2005) for three catchments in Quebec. Overall, the PROFILE WRs reported by Withfield et al. (2006) appeared to be particularly small. Most of the PROFILE input values that have an important positive impact on estimated WRs such as soil moisture, and specific surface area were higher in Withfield et al. (2006) than in our simulations. However, one major difference was the hornblende content 
in their reconstructed mineralogy (average of $0.6 \%$ ) which was 20 times lower than the average of our 21 catchments (13.4\%, Table 3) which certainly had an important impact on the estimated PROFILE WRs as shown by the high correlation between the hornblende content and $\mathrm{BC}+\mathrm{Na}$ and $\mathrm{Ca}$ and $\mathrm{Mg}$ weathering rates (Table 5). Withfield et al. (2006) potentially attributed the huge difference between their PROFILE estimation and catchment mass balance method to the poor representativeness of the soil profiles sampled and/or to an important contribution of the deep till or bedrock weathering which is not taken into account by weathering soil profile methods. Although we cannot evaluate the representativeness of the soil profiles sampled in our catchments, they were highly reproducible in terms of total element content (Table 2) and mineralogy (Table 3) within a given catchment as illustrated by the small standard errors. We also assumed that the sum of the B horizons contributes for the vast majority of the weathering of the whole soil profile based on the fact that the till deposit is relatively shallow for these types of catchment. Moreover, the soil solution $\mathrm{pH}$, as observed in intensively monitored calibrated forested catchment in Quebec (Houle et al., 1997; Duchesne and Houle, 2006, 2008), is often one order of magnitude (one $\mathrm{pH}$ unit) higher in the $\mathrm{C}$ horizon than in the B horizon which would considerably slow down the rates of weathering reactions.

Despite a relatively good agreement between PROFILE and net catchment exportations for $\mathrm{BC}+\mathrm{Na}, \mathrm{Ca}$ and $\mathrm{Mg}$ weathering rates, for $\mathrm{K}$ and $\mathrm{Na}$, the average ratios of the PROFILE WRs divided by net catchment exportations were 6.9 and 2.2 , respectively. We suggest that the huge difference observed for $\mathrm{K}$ is due to the fact that the catchments were not in steady state for $\mathrm{K}$, being currently accumulating the latter element, within and above the soil rooting zone. In fact, in the absence of major perturbations, $\mathrm{K}$ is efficiently retained (limited leaching losses) by tight recycling within the upper soil layers and the above ground vegetation (Duchesne and Houle, 2008, 2006; Likens et al., 1994). On the long-term, periods of net retention and net losses would be alternating as dictated by the intensity and frequency of insect infestations, forest fires or wind straws. A good example is the case of the spruce budworm outbreaks (that have a recurrence time of 32 years) on the $\mathrm{K}$ dynamics of boreal forests (Houle et al., 2009).

Contrary to $\mathrm{K}, \mathrm{Na}$ is considered as a conservative element within soils of forested catchments due to its very low affinity for soil-adsorbing surfaces and the minor requirements of biota for this element (Bailey et al., 2003; Duchesne and Houle, 2008). For these reasons, net Na catchment exportation is normally seen as a good surrogate to estimate Na WR (Bailey et al., 2003; Duchesne and Houle, 2006, 2008). The important discrepancy between WRs and net catchment exportations of $\mathrm{Na}$, as well as the absence of a significant correlation between these variables, is a matter of concern. Although the PROFILE model is successful in predicting the spatial variation in $\mathrm{Ca}$ and $\mathrm{Mg}$ lake concentrations as well as in providing reliable absolute values of $\mathrm{Ca}$ and $\mathrm{Mg}$ WRs, its capability to provide reliable Na WRs must be questioned. PROFILE is a very flexible model in regards to integrating plagioclase feldspar mineralogy. It has an albite component (90 to $100 \% \mathrm{NaAlSi}_{3} \mathrm{O}_{8}$ ) as well as a plagioclase component in which the increasing $\mathrm{Ca} / \mathrm{Na}$ ratios of oligoclase, andesine, labradorite, bytownite and anorthite (90 to $100 \%$ $\mathrm{CaAl}_{2} \mathrm{Si}_{2} \mathrm{O}_{8}$ ) can be specified. On the one hand, the difficulties in simulating Na WRs with PROFILE could be associated with the kinetic rate laws used to generate $\mathrm{Na}$ fluxes. On the second hand, the method limitations for estimating the complex assemblage of plagioclase feldspar minerals could also be a problem due to the method constraints in determining the $\mathrm{Ca} / \mathrm{Na}$ ratios of the plagioclase minerals present in the soils studied, the $\mathrm{Na}$ release rates could be overestimated if Na-rich plagioclase feldspars such as albite, oligoclase and andesine are overestimated in the assemblage. Because $\mathrm{Ca}$ can come in large part from hornblende and some other accessory minerals such as apatite, calcite and epidote (Bélanger and Holmden, 2010), the uncertainties with Na release from weathering in PROFILE are not necessarily reflected for Ca.

\section{Conclusions}

Given the importance of weathering processes in element cycling and particularly for forest nutrition, WRs of BCs were obtained for 21 forested catchments with the geochemical model PROFILE. Weathering rates of $\mathrm{BC}+\mathrm{Na}$ covered one order of magnitude ranging from 0.58 to $4.46 \mathrm{kmol}_{\mathrm{c}} \mathrm{ha}^{-1} \mathrm{yr}^{-1}$ within the study area. PROFILE WRs for $\mathrm{BC}+\mathrm{Na}, \mathrm{Ca}$ and $\mathrm{Mg}$ were significantly correlated with lake $\mathrm{BC}+\mathrm{Na}, \mathrm{Ca}$ and $\mathrm{Mg}$ concentrations as well as with net catchment exportations for the same variables. We conclude that the PROFILE model was able to adequately reproduce the spatial gradient in WRs within the study area. Although the range in annul air temperature may possibly account for a part of the observed gradient, difference in soil mineralogy was the main cause of the spatial variations. PROFILE WRs of $\mathrm{Ca}$ were not significantly different than the net catchment exportations. Although the assumption of steady state conditions for Ca cycling within the catchments cannot be tested, the good agreement between these two totally independent approaches (PROFILE and net exportations) for calculating WRs suggests that PROFILE can provide reliable estimation of WRs for Ca. On the other hand, PROFILE Mg WRs were significantly higher than net catchment exportations but by $51 \%$ which was considered a relatively small difference.

PROFILE WRs of $\mathrm{K}$ and Na did not correlate with neither, their respective lake concentrations or their net catchment exportations. Weathering rates of $\mathrm{K}$ and $\mathrm{Na}$ were also significantly higher than their net catchment exportations being 6.9 and 2.2 times higher, respectively. The huge differences for $\mathrm{K}$ should not be necessarily interpreted as a failure of the 
PROFILE model to correctly estimated K WRs. It is possible that that most of the $\mathrm{K}$ produced by weathering reactions was retained within soil catchments and/or above ground biomass. This explanation is in agreement with the low $\mathrm{K}$ catchment exportations observed in absence of perturbations (Duchesne and Houle, 2006, 2008). The Na weathering rates of PROFILE were significantly different (2.2 times higher) than net catchment exportations. This difference could be interpreted as relatively small given the uncertainties associated with the calculations of both approaches. However, the lack of agreement in terms of correlation between PROFILE $\mathrm{Na}$ WRs and net catchment exportations remains a matter of concern. Because $\mathrm{Na}$ is considered as fairly conservative in forest ecosystems, PROFILE was expected to be able to reproduce the spatial variability of $\mathrm{Na}$ WRs within the studied area. Further works should investigate this particular aspect of the PROFILE model.

Since PROFILE can provide reliable weathering rates for $\mathrm{BC}+\mathrm{Na}, \mathrm{Ca}$ and $\mathrm{Mg}$ and was able to account for the spatial variability within a relatively large geographical ensemble, it would be relevant in future attempts, to test the ability of PROFILE to reproduce long term temporal variation in weathering rates for selected catchments. Such an effort would permit to explore in more details the impact, on weathering rates calculations, of variables such as soil moisture and soil temperature that may substantially vary between years. In a context of global change, the latter variable could be critical to predict WRs in the future hydro-climatic environment of forest soils.

Acknowledgements. We would like to thank two anonymous reviewers and the handlind editor for their helpful comments on a previous version of the manuscript.

Edited by: P. Regnier

\section{References}

Anderson, S. P., Dietrich, W. E., and Brimhall, G. H.: Weathering profiles, mass-balance analysis, and rates of solute loss: Linkages between weathering and erosion in a small, steep catchment, Geol. Soc. Am. Bull., 114, 1143-1158, 2002.

Akselsson, C., Holmqvist, J., Alveteg, M., Kurz, D., and Sverdrup, H.: Scaling and mapping regional calculations of soil chemical weathering rates in Sweden. Water Air Soil Poll., 4, 671-681, 2004.

April, R., Newton, R., and Coles, L. T.: Chemical weathering in two Adirondack watersheds: Past and present-day rates, Geol. Soc. Am. Bull., 97, 1232-1238, 1986.

Arp, P. A. and Yin, X. W.: Predicting water fluxes through forests from monthly precipitation and mean monthly air temperature records, Can. J. Forest Sci., 22, 864-877, 1992.

Bailey, S. W., Buso, D. C., and Likens, G. E.: Implications of sodium mass balance for interpreting the calcium cycle of a forested ecosystem, Ecology, 84, 471-484, 2003.
Becker, R.: Critical load - PROFILE 4.2, Manual for the international PC version, OEKO-DATA, Strausberg, 46 pp., 1999.

Bélanger, N., Paré, D., Bouchard, M., and Daoust, G.: Is the use of trees with superior growth a threat to soil nutrient availability? A case study with Norway spruce, Can. J. Forest Sci., 34, 560-572, doi:10.1139/x03-216, 2004.

Bélanger, N. and Holmden, C.: Influence of landscape on the apportionment of $\mathrm{Ca}$ nutrition in a Boreal Shield forest of Saskatchewan (Canada) using $87 \mathrm{Sr} / 86 \mathrm{Sr}$ as a tracer, Can. J. Soil Sci., 90, 267-288, 2010.

Brantley, S. L. and White, A. F.: Approaches to Modeling Weathered Regolith, in: Thermodynamics and Kinetics of Water-Rock Interaction, edited by: Oelkers, E. H. and Schott, J., Rev. Mineral. Geochem., 70, 435-484, 2009.

Brimhall, G. H. and Dietrich, W. E.: Constitutive mass balance relations between chemical composition, volume, density, porosity, and strain in metasomatic hydrochemical systems: Results on weathering and pedogenesis, Geochim. Cosmochim. Acta, 51, 567-587, 1987.

Duchesne, L. and Houle, D.: Base cation cycling in a pristine watershed of the Canadian boreal forest, Biogeochemistry, 78, 195216, 2006.

Duchesne, L. and Houle, D.: Impact of nutrient removal through harvesting on the sustainability of the boreal forest, Ecol. Appl., 18, 1642-1651, 2008.

Eggenberger, U. and Kurz, D.: A soil acidification study using the PROFILE model on two contrasting regions in Switzerland, Chem. Geol., 170, 243-257, 2000.

Garrels, R. M. and Mackenzie, F. T.: Evolution of Sedimentary Rocks, W. W. Norton, New York, 1971.

Gislason, S. R., Oelkers, E. H., Eiriksdottir, E. S., Kardjilov, M. I., Gisladottir, G., Sigfusson, B., Snorrason, A., Elefsen, S., Hardardottir, J., Torssander, P., and Oskarsson, N.: Direct evidence of the feedback between climate and weathering, Earth Planet. Sc. Lett., 277, 213-222, doi:10.1016/j.epsl.2008.10.018, 2009.

Hodson, M. E. and Langan, S. J.: Considerations of uncertainty in setting critical loads of acidity of soils: the role of weathering rate determination, Environ. Pollut., 106, 73-81, 1999a.

Hodson, M. E. and Langan, S. J.: The influence of soil age on calculated mineral weathering rates, Appl. Geochem., 14, 387-394, 1999b.

Hodson, M. E., Langan, S. J., and Wilson, M. J.: A sensitivity analysis of the PROFILE model in relation to the calculation of soil weathering rates, Appl. Geochem., 11, 835-844, 1996.

Hodson, M. E., Langan, S. J., and Wilson, M. J.: A critical evaluation of the use of the PROFILE model in calculating mineral weathering rates, Water Air Soil Poll., 98, 79-104, 1997.

Houle, D., Paquin, R., Camiré, C., Ouimet, R., and Duchesne, L.: Response of the Lake Clair Watershed (Duchesnay, Quebec) to changes in precipitation chemistry (1988-1994), Can. J. Forest Sci., 27, 1813-1821, 1997.

Houle, D., Duchesne, L., Ouimet, R., Paquin, R., Meng, F. R., and Arp, P. A.: Evaluation of the FORHYM2 model for prediction of hydrologic fluxes and soil temperature at the Lake Clair Watershed (Duchesnay, Quebec), Forest Ecol. Manage., 159, 249-260, 2002.

Houle, D., Gagnon, C., Couture, S., and Kemp, A.: Recent recovery of lake water quality in southern Québec following reductions in sulfur emissions, Water Air Soil Poll., 4, 247-261, 2004. 
Houle, D., Ouimet, R., Couture, S., and Gagnon, C.: Base cation reservoirs in soil control the buffering capacity of lakes in forested catchments, Can. J. Fish. Aquat. Sci., 63, 471-474, 2006.

Houle, D., Duchesne, L., and Boutin, R.: Effects of a spruce budworm outbreak on element export below the rooting zone: a case study for a balsam fir forest, Ann. Forest Sci., 66, 1-9, 2009.

Houle, D., Couture, S., and Gagnon, C.: The relative role of decreasing precipitation sulfate and climate on recent lake recovery, Global Biogeoche. Cy., 24, GB4029, doi:10.1029/2009GB003757, 2010.

Jönsson, C., Warfvinge, P., and Sverdrup, H.: Uncertainty in predicting weathering rate and environmental stress factors with the profile model, Water Air Soil Poll., 81, 1-23, 1995.

Kirkwood, D. E. and Nesbitt, H. W.: Formation and evolution of soils from an acidified watershed: Plastic Lake, Ontario, Can. Geochim. Cosmochim. Acta, 55, 1295-1308, 1991.

Kolka, R. K., Grigal, D. F., and Nater, E. A.: Forest soil mineral weathering rates: Use of multiple approaches, Geoderma, 73, 121, 1996.

Koseva, I. S., Watmough, S. A., and Aherne, J.: Estimating base cation weathering rates in Canadian forest soils using a simple texture-based model, Biogeochemistry, 101, 183-196, 2010.

Lachance, M., Bobée, B., and Grimard, Y.: Sensitivity of southern Québec lakes to acidic precipitation, Water Air Soil Poll., 25, 115-132, 1985.

Langan, S., Fransson, L., and Vanguelova, E.: Dynamic modelling of the response of UK forest soils to changes in acid deposition using the SAFE model, Sci. Total Environ., 407, 5605-5619, 2009.

Likens, G. E. and Bormann, F. H.: Biogeochemistry of a Forested Ecosystem, 2nd Edn., Springer-Verlag, New York, 147 pp., 1995.

Likens, G. E., Driscoll, C. T., Buso, D. C., Siccama, T. G., Johnson, C. E., Lovett, G. M., Ryan, D. F., Fahey, T., and Reiners, W. A.: The Biogeochemistry of Potassium at Hubbard Brook, Biogeochemistry, 25, 61-125, 1994.

Ouimet, R. and Duchesne, L.: Base cation mineral weathering and total release rates from soils in three calibrated forest watersheds on the Canadian Boreal Shield, Can. J. Soil Sci., 85, 245-260, 2005.

Ouimet, R. and Duchesne, L.: Dépôts atmosphériques dans les forêts au Québec - Retombées actuelles et tendances au cours des 20 à 30 dernières années, Nat. Can., 133, 56-64, 2009.

Ouimet, R., Arp, P. A., Watmough, S. A., Aherne, J., and Demerchant, I.: Determination and mapping critical loads of acidity and exceedances for upland forest soils in Eastern Canada, Water Air Soil Poll., 172, 57-66, doi:10.1007/s11270-005-9050-5, 2006.

Pettijohn, F. J.: Persistence of heavy minerals and geologic age, J. Geol., 49, 610-625, 1941.

Régnière, J.: Generalized approach to landscape-wide seasonal forecasting with temperature-driven simulation models, Environ. Entomol., 25, 869-881, 1996.
Régnière, J. and Bolstad, P.: Statistical simulation of daily air temperature patterns eastern North America to forecast seasonal events in insect pest management, Environ. Entomol., 23, 13681380, 1994.

Régnière, J. and St-Amant, R.: Stochastic simulation of daily air temperature and precipitation from monthly normals in North America north of Mexico, Int. J. Biometeorol., 51, 415-430, doi:10.1007/s00484-006-0078-z, 2007.

Stillings, L. L. and Brantley, S. L.: Feldspar dissolution at $25^{\circ} \mathrm{C}$ and $\mathrm{pH}$ 3: Reaction stoichiometry and the effect of cations, Geochim. Cosmochim. Acta, 59, 1483-1496, 1995.

Sverdrup, H. and Warfvinge, E.: Weathering of primary silicate minerals in the natural soil environment in relation to a chemicalweathering model, Water Air Soil Poll., 38, 387-408, 1988.

Sverdrup, H. and Warfvinge, P.: Critical load, in: Modelling groundwater response to acidification, edited by: Sandén, P. and Warfvinge, P., SMHI Reports Hydrology No. 5, Swedish Meteorological and Hydrological Institute, Norrköping, 171-186, 1992.

Sverdrup, H. and Warfvinge, P.: Calculating field weathering rates using a mechanistic geochemical model PROFILE, Appl. Geochem., 8, 273-283, 1993.

Sverdrup, H. and Warfvinge, P.: Critical Loads of Acidity for Swedish Forest Ecosystems, Ecol. Bull., 44, 75-89, 1995.

Sverdrup, H. U.: The kinetics of base cation release due to chemical weathering, Lund University Press, Lund, 246 pp., 1990.

Taylor, A. B. and Velbel, M. A.: Geochemical mass balances and weathering rates in forested watersheds of the southern Blue Ridge, II: Effects of botanical uptake terms, Geoderma, 51, 29$50,1991$.

Wallander, H.: Use of strontium isotopes and foliar K content to estimate weathering of biotite induced by pine seedlings colonised by ectomycorrhizal fungi from two different soils, Plant. Soil., 222, 215-229, 2000.

Warfvinge, P. and Sverdrup, H.: Critical loads of acidity to Swedish forest soils: methods, data and results, Lund University, Department of Chemical Engineering II, Lund Technical report in ecology and environmental engineering 5, 1995.

Warfvinge, P., Falkengren-Grerup, U., Sverdrup, H., and Andersen, B.: Modelling long-term cation supply in acidified forest stands, Environ Poll., 80, 209-221, 1993.

White, A. F., Blum, A. E., Bullen, T. D., Vivit, D. V., Schulz, M., and Fitzpatrick, J.: The effect of temperature on experimental and natural chemical weathering rates of granitoid rocks, Geochim. Cosmochim. Acta, 63, 3277-3291, 1999.

Whitfield, C. J., Watmough, S. A., Aherne, J., and Dillon, P. J.: A comparison of weathering rates for acidsensitive catchments in Nova Scotia, Canada and their impact on critical load calculations, Geoderma, 136, 899-911, doi:10.1016/j.geoderma.2006.06.004, 2006.

Yin, X. W. and Arp, P. A.: Predicting forest soil temperatures from monthly air temperature and precipitation records, Can. J. Forest Sci., 23, 2521-2536, 1993. 